\title{
Long-term efficacy and safety of once-daily mesalazine granules for the treatment of active ulcerative colitis
}

This article was published in the following Dove Press journal:

Clinical and Experimental Gastroenterology

23 September 2014

Number of times this article has been viewed

\author{
Stephan Karl Böhm' \\ Wolfgang Kruis ${ }^{2}$ \\ 'Kantonsspital Baselland, Medizinische \\ Universitätsklinik, Bruderholz, \\ Switzerland; ${ }^{2}$ Evangelisches \\ Krankenhaus Kalk, University \\ of Cologne, Cologne, Germany
}

Abstract: In 1977, 5-aminosalicylic acid (5-ASA) was discovered as a therapeutically active moiety of sulfasalazine (SASP) and was launched for topical and oral therapy of ulcerative colitis (UC) in 1984. As a first-step, delivery systems had to be developed to protect 5-ASA against absorption in the upper gastrointestinal tract, resulting in different and competing strategies (azo compounds, controlled release, and $\mathrm{pH}$-dependent release). In a second step, at the beginning of the new century, coinciding with the expiration of patent protection for the first 5-ASA formulations, two component composite release mechanisms (pH-dependent and controlled release) were developed. Furthermore, the drug was formulated as granules instead of tablets, allowing higher unit strengths compared with tablets. Neither Salofalk Granu-Stix ${ }^{\circledR}$, nor MMX 5-ASA, nor Pentasa ${ }^{\circledR}$ granules have initially been developed for once-daily (OD) dosing. A review of the achievements of 20 years of 5-ASA development has demonstrated that 5-ASA has equal efficacy compared with SASP at best, that there are no measurable differences in efficacy between various 5-ASA preparations, and that in a group of patients tolerating SASP, adverse event profiles of SASP and 5-ASA did not differ significantly, with SASP being the far cheaper substance. Therefore, drug adherence came into focus as a new goal for improving UC therapy. Although adherence is a complex and multifactorial construct, a simple dosing schedule may contribute to higher drug adherence and better efficacy of treatment. Simultaneously, the US 5-ASA market, estimated to be worth US\$1.4 billion, is expected to grow continuously. Naturally, this very competitive market is not only driven by scientific progress but also by commercial interests. Thus, patents for minor changes to the formulation may serve as protection against drug companies trying to launch generic versions. Randomized controlled trials performed on OD dosing in induction of remission have demonstrated that OD administration of 5-ASA is as effective as conventional dosing in mild to moderate active UC. The three 5-ASA products MMX, Salofalk ${ }^{\circledR}$, and Pentasa ${ }^{\circledR}$ employed in those studies so far have not shown differences in efficacy between OD and conventional dosing. No differences regarding safety outcomes have been detected between OD and conventional dosing, including incidence of adverse events, serious adverse events, or withdrawal from treatment due to an adverse event. Although the majority of patients prefer OD dosing to conventional dosing, it was not possible to detect differences in adherence between OD and multiple dose regimens in the clinical trial setting. Well-designed and controlled large-scale community-based studies are necessary to further investigate and prove the point of improved long-term adherence and treatment efficacy in OD dosing.

Keywords: dosing, adherence, mesalamine, 5-aminosalicylic acid

\section{Introduction}

Ulcerative colitis (UC) is a chronic inflammatory disorder involving the colonic mucosa. Most frequently, the mucosal inflammation involves the rectum, but it may
Kantonsspital Baselland,

4I0I Bruderholz, Switzerland

Email stephan.boehm@ksbl.ch 
extend proximally, resulting in procto-sigmoiditis, left-sided colitis, or pancolitis. In addition, patients may suffer from extraintestinal manifestations of UC, including affections of the skin, eyes, joints, or the liver in the form of primary sclerosing cholangitis. In addition, there is an increased risk for colorectal cancer, with longstanding inflammation. UC most commonly affects teenagers and young adults, but may occur in any age group. ${ }^{1}$ The prevalence in the US adult population is 238 per 100,000 , and the worldwide incidence varies from 0.5 to 24.5 per 100,000 person-years. ${ }^{2,3}$ The clinical presentation includes bloody diarrhea, rectal urgency, tenesmus, and abdominal cramping. UC follows a relapsing and remitting course necessitating therapy for induction of remission as well as maintenance of remission. 5-aminosalicylic acid (5-ASA) (the terms 5-ASA, mesalazine, and mesalamine are synonymous) was introduced into UC therapy 30 years ago and remains the backbone of treatment in both indications. Thus, for induction of remission, current national and international guidelines recommend oral 5-ASA alone or in combination with topical application in the management of active mild to moderate left-sided or extensive UC. ${ }^{4-6}$

Lately, 5-ASA formulations developed more than 10 years ago for a multiple daily dosing schedule have been marketed for once-daily (OD) dosing. Adherence issues have been cited as the main reason for this shift. According to this hypothesis, a more inconvenient drug regimen can interfere with the everyday life of a patient, reduce quality of life, and thus have a negative impact on adherence to the drugs, resulting in a poorer long-term prognosis.

In this review, we trace the evolution of 5-ASA formulations, examine the rationale and motivation for the introduction of OD dosing in UC therapy, and sum up efficacy and safety of oral 5-ASA in the treatment of active UC administered OD following this new therapeutic trend.

\section{The path to OD dosing of oral 5-ASA \\ Sulfasalazine}

The development of modern treatment of UC started with the introduction of sulfasalazine (SASP) by the Swedish physician Nanna Svartz in 1942. Serving as Professor of Internal Medicine at the Karolinska Institute from 1937 to 1957, she was the first woman ever to be appointed professor at a Swedish university. ${ }^{7}$ Svartz synthesized and described SASP as anti-inflammatory principle in rheumatic arthritis and UC. SASP contains 5-ASA bound to sulfapyridine via a diazobond. This bond is cleaved by bacterial azoreductases in the colon to release the two components and thus deliver 5-ASA to the intended site of action. ${ }^{1,8}$

\section{Identification of 5-ASA as the therapeutically active component}

Indeed, about 35 years ago, 5-ASA was found to be the therapeutically active moiety, while sulfapyridine is thought to function as the inactive carrier molecule. ${ }^{9-11}$ Sulfapyridine is absorbed into the systemic circulation and is believed to be mostly responsible for the adverse effects associated with SASP. ${ }^{12,13}$ Oral administration of unbound or uncoated 5-ASA results in rapid and nearly complete absorption by the proximal small bowel and conversion to the inactive metabolite N-acetyl-5-ASA, thus preventing delivery of therapeutically sufficient concentrations to the colon where it supposedly acts locally on the mucosa. ${ }^{1,8,14,15}$ Therefore, key factors governing the development of 5-ASA formulations are minimizing systemic absorption of 5-ASA from the small intestine and maximizing delivery of the active drug to the site of inflammation in the colon. ${ }^{16,17}$

\section{Mechanism of action}

A number of different but not mutually exclusive mechanisms of action have been proposed for the polypotent 5-ASA, including inhibition of the activity of the nuclear factor-kappa B (NF- $\kappa \mathrm{B})$ pathway. ${ }^{18-22}$ Lately evidence is accumulating that the anti-inflammatory effects of 5-ASA are mediated, at least in part, by peroxisome proliferator-activated receptor gamma (PPAR $\gamma) .^{1,23,24} \operatorname{PPAR} \gamma$ is a nuclear receptor that modulates the inflammatory response of monocytes and macrophages by inhibiting the production of nitric oxide (iNOS) and macrophage-derived cytokines such as tumor necrosis factor (TNF)- $\alpha$, interleukin (IL)-1, and IL-6. ${ }^{1}$ Novel PPAR $\gamma$ modulators having similarities to 5-ASA have been developed, one of them (GED-0507-34-Levo) is evaluated in Phase 2 clinical trials with promising results. ${ }^{24}$

\section{Pharmacokinetics}

The pharmakokinetic profiles of oral mesalazine formulations and mesalazine pro-drugs have been extensively reviewed. ${ }^{16}$ Another paper reviews whether pharmacological methods for assessing 5-ASA release and colonic distribution from oral formulations are useful for guiding clinical decisions. The strengths and weaknesses of in-vitro gastrointestinal models, gamma-scintigraphy, plasma pharmacokinetic studies, and mucosal biopsies are discussed. The latter provide direct evidence of colonic distribution and may predict clinical efficacy, but must be interpreted cautiously because of 
considerable inter-subject variability and other confounding factors. The paper concludes that limitations of individual measurement techniques mean that randomized clinical studies in UC patients remain the best guide for dosing and treatment regimen decisions. ${ }^{25}$

\section{Topical 5-ASA formulations}

The requirements of minimizing systemic absorption of 5-ASA from the small intestine and maximizing delivery of the active drug to the site of inflammation in the colon are ideally met by topical 5-ASA formulations like suppositories, foam, or enemas. ${ }^{17,26}$ Topical 5-ASA formulations result in 200-fold higher mucosal concentrations than those achieved by oral administration. Data from clinical trials show that topical 5-ASA therapy is superior to oral therapy in distal $\mathrm{UC}$ and is an important part of the therapy in more extensive forms of UC up to pancolitis and is therefore recommended in current international guidelines. ${ }^{4,6,27,28}$ Topical use of 5-ASA was first described in 1981. ${ }^{26}$ Dr Falk Pharma's (Freiburg, Germany) $250 \mathrm{mg}$ Salofalk $^{\circledR}$ suppositories launched in March 1984 were the first pure 5-ASA preparation worldwide. By the early 1990s, topical 5-ASA was considered firmly established in UC therapy. ${ }^{29}$ Since about $80 \%$ of UC patients suffer from proctitis or left-sided colitis, ${ }^{30}$ it is all the more surprising that between 1992 and 2009 prescriptions for oral 5-ASA increased nearly six-fold, while those for topical 5-ASA remained almost constant at a low 10\% share of the entire 5-ASA market. ${ }^{27}$ Reasons for this disparity cited are patient discomfort or inconvenience caused by topical therapy, the opinion held by many practitioners that patients with active colitis have difficulties retaining rectal suspensions, and more aggressive marketing of oral 5-ASA preparations with patented release mechanisms claiming to enhance distal colon 5-ASA release. ${ }^{17,27,31}$

\section{First-generation oral 5-ASA formulations}

Only a few months after the suppositories, Dr Falk Pharma introduced also in 1984 the first pure oral 5-ASA preparation $\left(\right.$ Salofalk $\left.^{\circledR}\right)$, that was protected against absorption in the upper gastrointestinal tract by a $\mathrm{pH}$-sensitive acrylic coating (Eudragit L) that delays 5-ASA release until luminal conditions approach $\mathrm{pH} 7$, the $\mathrm{pH}$ present in the terminal ileum and cecum. ${ }^{8,16,17,27}$ Other formulations using this strategy include Claversal ${ }^{\circledR}$ (1987; Merkle, Blaubeuren, Germany) and Asacol ${ }^{\circledR}$ (1988; Medeva Pharma Suisse, Bulle, Switzerland), Pentasa ${ }^{\circledR}$ (1986; Ferring; Saint-Prex, Switzerland) is a microsphere formulation that consists of 5-ASA microgranules enclosed within a semipermeable membrane of ethylcellulose, which is designed for controlled drug release that begins in the duodenum and continues into the affected regions of the lower bowel.

Another strategy of protecting 5-ASA from early absorption is incorporation of 5-ASA into a prodrug, in which 5-ASA is covalently bound to an active carrier molecule. Examples for this prodrug strategy other than SASP are olsalazine/Dipentum ${ }^{\circledR}$ (1990; UCB Pharma, Anderlecht, Belgium). which consists of two 5-ASA molecules linked by a diazo bond or balsalazide/Colazal ${ }^{\circledR} /$ Colazide $^{\circledR}(1998$ Salix Pharmaceuticals Inc., Raleigh, NC, USA; Almirall, Barcelona, Spain), which is composed of a 5-ASA molecule azo-bonded to a benzoic acid derivative. Like SASP, these compounds are poorly absorbed in the upper digestive tract but are readily metabolized by bacterial diazoreductases of the intestinal flora in the lower bowel. $8,16,17,27$

It should be mentioned that for some of these 5-ASA products invention, production, and distribution lie in different hands, and those may differ between continents or even between countries in Europe. Importantly, a formulation in one country may not be identical to a formulation with the same name produced in a different country. For example, for $\mathrm{Asacol}^{\circledR}$, differences with respect to the $\mathrm{pH}$ at which 5-ASA is released, the overall dissolution profile, efficacy and safety have been described between tablets produced in the US and within Europe..$^{32,33}$

The unit strength for the controlled-release 5-ASA products range between 250 and $500 \mathrm{mg}$, with daily target doses between 1.6 and $4.8 \mathrm{~g}$ for active $\mathrm{UC}$ and 0.75 and $4.8 \mathrm{~g}$ for maintenance, resulting in a number of units to swallow per day of up to 16 . In the case of the azo compounds, unit strengths between 250 and $750 \mathrm{mg}$ were available with daily target doses of 2.00-6.75 $\mathrm{g}$ for active UC and 1.00-6.75 $\mathrm{g}$ for maintenance, resulting in up to nine pills per day (16). The first 5-ASA product offered in a unit strength of $1,000 \mathrm{mg}$ was Pentasa ${ }^{\circledR}$ in $1999 .{ }^{34,35}$

\section{Second-generation oral 5-ASA formulations}

To offer the $1,000 \mathrm{mg}$ unit strength, the Pentasa ${ }^{\circledR}$ microgranules were no longer packaged into a tablet, which would have been difficult to swallow because of its size, but loosely filled into a sachet. Arguments for this product alteration were the necessity of administration of higher daily 5-ASA doses as a result of meta-analyses at that time finding a dose-response relationship and the resulting inconvenience of taking large amounts of tablets. The compliance issue was also mentioned..$^{34,35}$ Lately, data were presented that patients indeed prefer granules over tablets. ${ }^{36}$ Interestingly, the paper 
dealing with the pharmacology of the new preparation is also discussing the use of systemic bioequivalence data in the regulatory assessment of marketing authorities for generic or copy products in locally acting preparations. ${ }^{34}$ Indeed, at the beginning of the new century, the available oral 5-ASA products were reaching the end of their formulation patent protection, and 5-ASA copies were expected to compete with the proprietary products. ${ }^{33}$ For example, in 2003, Lagap Pharmaceuticals Ltd, now Sandoz Ltd, launched with Ipocol a copy of Asacol ${ }^{\circledR}$ with $400 \mathrm{mg}$ 5-ASA in a Eudragit S coating, although with different characteristics. ${ }^{37}$ Therefore, modifications of 5-ASA products in the early 2000s were probably in part also driven by patent issues.

In 2005, Claversal ${ }^{\circledR}$, similarly to Pentasa ${ }^{\circledR}$, was also offered as a multi-unit 1,500 mg micropellet sachet in addition to the single-unit tablets. ${ }^{38,39}$

While Pentasa ${ }^{\circledR}$ and Claversal ${ }^{\circledR}$ were now basically just marketed as a multi-unit instead of a single-unit drug at a higher dose, Dr Falk Pharma developed its Salofalk ${ }^{\circledR}$ one step further. Salofalk Granu-Stix ${ }^{\circledR}$ launched in 2001 was now to release 5-ASA in a first-step pH-dependent by depolymerization of the acrylic coating and in a second step from a matrix core, that is designed to provide a continuous release of 5-ASA even in the distal colon. In vitro dissolution and plasma concentration data suggested a slower and more prolonged release of 5-ASA from the pellets compared with the tablets. An in vivo pharmacologic and scintigraphic study demonstrated that the novel 5-ASA pellets and Salofalk ${ }^{\circledR}$ tablets release active 5-ASA in the same target region and pass through the gastrointestinal tract under fasting conditions in healthy volunteers in a comparable time. ${ }^{40}$ Salofalk Granu-Stix $^{\circledR}$ were marketed as 500 and 1,000 mg sachets. They were, however, not specifically developed for OD dosing. In a dose-finding study in $\mathrm{UC}$, the drug regimen was three times a day (TID). ${ }^{41}$

A similar two-component drug-release mechanism was employed by Italy's pharmaceutical company Giuliani SpA in developing its multi-matrix (MMX) 5-ASA. The molecule is incorporated into a lipophilic matrix, which is itself dispersed within a hydrophilic matrix, to delay and prolong dissolution. Similar to other 5-ASA products a gastroresistent polymer film leads to $\mathrm{pH}$-dependent dissolution of the tablet at $\mathrm{pH} 7$ in the terminal ileum. The hydrophilic matrix is then exposed to intestinal fluids and swells, resulting in the formation of a viscous gel mass supposedly leading to a slow gradual release of mesalazine throughout the length of the colon. ${ }^{42}$ The pharmacoscintigraphic study to evaluate its in vivo properties came to the conclusion that 5-ASA was mainly and selectively delivered to the colonic lumen, with a continuous release along the whole colon, and a lower systemic absorption was observed compared with other mesalazine sustained-release formulations. ${ }^{43}$ The MMX 5-ASA tablet has a unit strength of $1,200 \mathrm{mg}$, nevertheless, similar to the other 5-ASA products, it was not primarily developed for OD dosing. The schedule in the pharmacological study was twice a day (BID); in the first clinical study even TID. ${ }^{44}$ MMX 5-ASA was launched in 2007 by Shire (Basingstone, UK) as Lialda ${ }^{\circledR}$ and Mezavant ${ }^{\circledR}$ in the US and European markets, respectively.

\section{Drawing the balance after 20 years of 5-ASA development}

5-ASA preparations were intended to avoid the adverse effects of SASP while maintaining its therapeutic benefits. After more than 20 years of development of multiple competing oral 5-ASA formulations, Sutherland and MacDonald ${ }^{8,45}$ measured the progress been made in their Cochrane systematic review on oral 5-ASA in induction and maintenance of remission of UC, published in 2006. The result was sobering in three regards:

- Efficacy of 5-ASA versus SASP

For maintenance of remission, SASP was found to have a higher degree of therapeutic effectiveness compared with 5-ASA, with an odds ratio of 1.29 (95\% confidence interval [CI] 1.05-1.57). For induction of remission studies, investigating complete global or clinical remission found no difference between SASP and 5-ASA; only for endoscopic improvement was there a trend toward the superiority of 5-ASA over SASP, which did not reach statistical significance. ${ }^{8,45}$

- Adverse events of 5-ASA versus SASP

Regarding adverse events in the maintenance situation SASP and 5-ASA had similar profiles, with odds ratios of 1.16 (95\% CI 0.62-2.16) and 1.31 (95\% CI 0.86-1.99), respectively. The NNH (number needed to harm) values were determined to be 171 and 78, respectively. However, it is mentioned that there may have been a bias in favor of SASP, since many trials comparing 5-ASA and SASP involved patients who were known to have tolerated SASP in the past. This might have minimized SASP-related adverse events in these trials. ${ }^{45}$ The metaanalysis examining induction of remission trials found a significantly higher proportion of withdrawals associated with SASP. ${ }^{8}$

- Differences in efficacy between various 5-ASA preparations 
Both reviews arrive at the conclusion that there is little evidence to suggest that there are differences in the efficacy of various oral 5-ASA drugs. This conclusion was also bolstered by more recent studies comparing a pH-dependent $\left(\right.$ Asacol $\left.^{\circledR}\right)$ and a time-dependent $\left(\right.$ Pentasa $^{\circledR}$ ) 5-ASA formulation ${ }^{46}$ as well as Asacol ${ }^{\circledR}$ with MMX. ${ }^{47}$

Incidentally, the updated versions of the pair of Cochrane systematic reviews in 2012 corroborated those results further. ${ }^{48,49}$

The authors drew the following conclusions for practice and research:

- In the light of the fact "that the newer 5-ASA preparations have yet to be proven to be more clinically beneficial than SASP" and that they are three to four times more expensive than SASP, they "should be reserved for SASP-intolerant individuals, men concerned about fertility, and other patients within special populations that may, in the future, be shown to gain unique therapeutic benefits from alternative 5-ASA delivery systems." ${ }^{, 45}$ A share of $25 \%$ for SASP among 5-ASA prescriptions in the US testifies to the continued value of SASP in daily practice. $^{27}$

- "There is little evidence to suggest that there is a difference in efficacy of the oral 5-ASA drugs. Given, that the differences in efficacy are likely to be marginal, further trials comparing the efficacy of various 5-ASA agents do not appear to be justified. Future trials should look at enhancing patient adherence with medication rather than comparing the efficacy of various 5-ASA agents. Adherence to therapy is important for treatment success and may be an important predictor of relapse." ${ }^{, 45}$

Thus a lack of substantial progress in efficacy and safety contributed to a shift of focus in 5-ASA drug development or rather marketing to the topic of adherence. Two important issues regarding this field are the dosing schedule (ie, multiple daily dosing versus OD dosing, as well as total dose).

\section{Adherence and OD dosing}

In chronic diseases like UC, therapy often must continue on an indefinite basis; this is especially true for the maintenance situation. This can result in significant levels of medication non-adherence. ${ }^{50-52}$

\section{Prevalence of medication non-adherence in inflammatory bowel disease}

While clinical trials in the inflammatory bowel disease (IBD) field report patient adherence rates between $70 \%$ and $95 \%$, in normal clinical practice non-adherence rates being defined as taking less than $80 \%$ of prescribed medication, range between $40 \%$ and $72 \% .^{53-56}$

\section{The impact of non-adherence on clinical recurrence}

A cohort study of 99 UC patients in remission demonstrated a considerable impact of non-adherence on clinical recurrence. ${ }^{57}$ Patients who were non-adherent to their prescribed 5-ASA therapy had a greater than fivefold increased risk of clinical relapse. Moreover, adherent patients were shown to have an $89 \%$ chance of maintaining remission, compared with only $39 \%$ in non-adherent patients. ${ }^{57}$ Other consequences of non-adherence to 5-ASA therapy are an increased risk of developing colon cancer and increased health care costs. ${ }^{51,52,56}$

\section{Reasons for non-adherence}

Adherence is a complex and multifactorial issue, in which a wide variety of factors play a role (eg, poor physician-patient relationship, lack of insight into illness, perceptions and beliefs about the illness, treatment of asymptomatic disease, and forgetfulness). Therefore, dosing regimen is just one of many factors potentially influencing drug adherence. ${ }^{51,52,56}$ Nevertheless, the dosing schedule as a potential avenue to improve therapeutic outcome in UC has been addressed already, some 30 years ago. Van Hees and van Tongeren ${ }^{58}$ measured urine levels of acetylated SASP as a marker for adherence and found considerably lower urine levels months after hospital discharge in $41.2 \%$ of patients. They suggested investigating whether SASP can be given BID in maintenance therapy instead of TID or QID (four times daily), citing studies from the late 1960s and early 1970s, which had demonstrated much higher adherence for BID schedules. $^{58}$

\section{OD dosing}

A meta-analysis by Claxton et $\mathrm{al}^{59}$ published in 2001 examined the relationship between number of daily doses and rate of adherence. It included studies where adherence was measured only by electronic monitoring and excluded studies based on patient self-report, blood-level monitoring, prescription refills, or pill count data. A total of 76 studies from several disease areas were identified. The result suggested that less frequent dosing is related to higher adherence. However, significant differences were only demonstrated between OD and three-times daily, or four-times daily dosing. No significant difference was found between OD and BID regimens. ${ }^{59}$ 


\section{First steps}

The pioneers of OD dosing of 5-ASA in UC were Hussain et al, ${ }^{60}$ who performed a pharmacokinetic study published in 2001, and Kane et al, ${ }^{50}$ who undertook a first pilot feasibility study of OD versus conventional dosing for maintenance in UC, published in 2003.

In the pharmacokinetic study 12 healthy volunteers each received either 1.2 or $2.4 \mathrm{~g}$ of Eudragit S-coated 5-ASA $\left(\right.$ Asacol $^{\circledR}$ ) either as three doses of 400 and $800 \mathrm{mg}$, respectively, or as an OD dose for 7 days. Peak and trough serum levels and serum area under the curve values were similar with both regimens. Furthermore, urinary, fecal, and most importantly, rectal tissue concentrations were similar following single or divided dosing. The authors suggested clinical trials examining efficacy and toxicity of OD dosing in patients with UC. ${ }^{60}$

In the clinical pilot study, 22 patients with UC in remission were randomized to OD 5-ASA versus conventional dosing (BID or TID), with the exact 5-ASA formulation and dose not further specified to assess adherence rates with both regimens. At 6 months nine patients (75\%) in the OD group versus seven (70\%) in the conventional dosing group were adherent. However, the amount of medication taken approached significance ( $90 \%$ versus $76 \%, P=0.07$ ), and all patients in the OD group reported being either "very satisfied" or "satisfied" with their regimen. The performance of larger trials was suggested. ${ }^{50}$

In 2007, a further pharmacokinetic study compared an OD dosing regimen of $4 \mathrm{~g}$ Pentasa ${ }^{\circledR}$ with the current twice-daily dosage of $2 \times 2 \mathrm{~g} /$ day. Similar to the previous study of Hussein et al, ${ }^{60}$ concentrations of 5-ASA and its metabolites were similar in plasma, urine, feces, and rectal tissue following single or divided daily dosing in 30 healthy volunteers. ${ }^{61}$

\section{OD dosing and safety considerations}

It was also in 2007 when a host of studies started to be published exploring the effect of OD dosing versus conventional dosing on efficacy, safety, and adherence on a broader basis. Interestingly, safety concerns of employing OD dosing, which could potentially result in a higher peak dosis in the patient, are barely discussed in the literature. After all, the practice of divided dosing stemmed from the desire to reduce the toxicity and side effects that were originally associated with SASP therapy. ${ }^{62,63}$ It may be speculated that it was reasoned that the high OD 5-ASA doses would be well tolerated because the pharmacokinetic study of Hussain et $\mathrm{al}^{60}$ had not found relevant differences between OD and conventional dosing, and newer 5-ASA agents are generally tolerated better than SASP.

\section{Dose-response relationship}

Another important aspect closely related to safety and efficacy is the issue of dose-response relationship. Safety might depend on the total dose necessary to gain efficacy. In this respect, it was observed early on that the clear dose-response relationship established for SASP between 1 and $18 \mathrm{~g}$ could not be reproduced for 5-ASA compounds. Related to dosedependent side effects of SASP, commonly $4 \mathrm{~g}$ daily for active disease and $2 \mathrm{~g}$ for maintenance treatment, providing 1,600 and $800 \mathrm{mg} 5$-ASA, respectively, are used as a compromise between efficacy and safety. ${ }^{64}$ While studies have shown 5-ASA compounds to be as effective as 3-4 g SASP, none has been superior, even with doses of $4.8 \mathrm{~g}$ 5-ASA, equivalent to $12 \mathrm{~g}$ SASP, suggesting there is more to the action of SASP than delivering 5-ASA to its site of action. ${ }^{64}$ The meta-analysis by Sutherland and MacDonald ${ }^{8,45}$ states no dose-response trend for the maintenance situation, while a dose-response trend was observed for induction therapy.

The ECCO (European Crohn's and Colitis Organisation) guideline from 2012 states that for maintenance of remission, there is a minimum effective dose of oral 5-ASA of $1.2 \mathrm{~g}$ per day. In the comment, it is explained that a dose-response for maintenance of remission with mesalazine at doses greater than $0.8 \mathrm{~g} /$ day has not been established. It is possible that higher doses of maintenance oral mesalazine are required in some patients, perhaps in those that require high doses of oral 5-ASA to induce remission or those with frequently relapsing disease, but at present, there is no robust evidence to support this. ${ }^{4,4865}$ For treatment of left-sided or extensive active colitis of mild to moderate severity, use of oral 5-ASA at a dose $>2 \mathrm{~g}$ is recommended. An advantage for doses beyond $2 \mathrm{~g}$ was suggested regarding response and mucosal healing but not remission, in the Assessing the Safety and Clinical Efficacy of a New Dose of 5-ASA (ASCEND) II study. ${ }^{66,67}$ The ASCEND III study suggested a benefit of the higher dose strategy for induction of remission (43\% versus $35 \%$; $P=0.04),{ }^{68}$ while a study with MMX did not demonstrate a benefit of $4.8 \mathrm{~g} /$ day compared to $2.4 \mathrm{~g}$ /day at 8 weeks. ${ }^{69}$

In summary, patient adherence is an important issue in the attempt to improve therapy of UC. Simplifying the dosing schedule and adapting it to the needs of the patient can be one element of improving drug adherence. A missing clear dose-response relationship limiting the maximal doses, pharmacokinetic studies demonstrating comparable results between OD and conventional dosing and overall 
good tolerability of 5-ASA compounds allowed clinicians and drug companies to follow the avenue of OD dosing in the therapy of UC.

\section{Market}

Innovation - or pseudo-innovation in some cases - in drug development is not only driven by scientific progress, but naturally also by commercial interests. 5-ASA has been in clinical use now for 30 years; patents on the substance have long expired. The last significant changes to the formulation were made almost 15 years ago, and those patents are expiring as well. The market is more and more challenged from companies specializing in generics. A market with a considerable volume is to be protected.

\section{Market volume}

According to numbers from 2009, the US 5-ASA market was estimated to be worth US\$1.4 billion, with continuing growth being expected. ${ }^{1}$ While the Shire plc ${ }^{70}$ annual report, 2010 claims that $88 \%$ of all UC patients receive treatment with 5-ASA, a German health insurer covering 8.6 million people gives a lower number, with $49 \%{ }^{71}$ Those insured with Barmer GEK had 5-ASA prescriptions worth $€ 14.2$ million in 2012, a little down from 2011, with $€ 14.5$ million. ${ }^{72}$ The fraction of patients receiving 5-ASA for the treatment of Crohn's disease ranges from $16 \%$ to $31 \%$, depending on the source. ${ }^{71,73}$

The 5-ASA market is highly competitive, with several companies offering their products to physicians and patients. Tables 1 and 2 show the market share of different products in the US and the European markets for the year 2010 and 2010/2011, respectively. The market is especially under pressure, since mesalamine and balsalazide products are generally protected by formulation patents only, and generic drug companies are looking to make a push into the 5-ASA market.

Table I Market shares of oral 5-aminosalicylic acid products in the 2010 United States market ${ }^{70}$

\begin{tabular}{llll}
\hline Product & Manufacturer & Licensed to & $\begin{array}{l}\text { Market } \\
\text { share, \% }\end{array}$ \\
\hline Asaco $^{\circledR}$ & Medeva Pharma Suisse & Warner-Chilcott & 42.4 \\
Lialda $^{\circledR}$ & Shire & & 20 \\
Pentasa $^{\circledR}$ & Ferring & Shire & 14 \\
Asacol HD $^{\circledR}$ & Warner-Chilcott & & 9 \\
Balsalazide $^{\circledR}$ & Generic & & 6.9 \\
Apriso $^{\circledR}$ & Dr Falk & Salix & 6 \\
Colazal $^{\circledR}$ & Salix & & 0.9 \\
Dipentum $^{\circledR}$ & UCB & Alaven Pharm LLC & 0.6 \\
\hline
\end{tabular}

\section{Competition through expiring patents}

Salix's patent on its balsalazide-containing product Colazal ${ }^{\circledR}$ expired in 2007. The company fought since 2005 against approval of generic versions of Colazal ${ }^{\circledR}$ and was denied by the US Food and Drug Administration (FDA) in 2007. Salix subsequently announced the launch of an authorized generic version by Watson Pharmaceuticals; the FDA approved subsequently also three other generic versions of Colazal ${ }^{\circledR}$, which had a $6.9 \%$ and $7.5 \%$ share of the US oral market in December 2010 and December 2011, respectively. ${ }^{70}$ In an attempt to offset the loss of patent protection of Colazal ${ }^{\circledR}$, Salix acquired rights to develop Dr Falk Pharma's mesalamine granules and received approval from the FDA in October 2008 to market the granules packaged in $375 \mathrm{mg}$ capsules as Apriso ${ }^{\circledR}$ in the US. Apriso ${ }^{\circledR}$ was supposed to be patent-protected until 2018. In September 2012, Salix Pharmaceuticals and Dr Falk Pharma filed a lawsuit against the Indian drug company Lupin Ltd for patent infringement. Lupin seeks approval to market a generic version of Apriso ${ }^{\circledR}$.

The patent for Asacol ${ }^{\circledR}$ expired in July 2013. In 2009, Proctor and Gamble launched (Cincinnati, OH, USA) launched an $800 \mathrm{mg}$ mesalamine tablet as Asacol $\mathrm{HD}^{\circledR}$ in addition to its $400 \mathrm{mg}$ tablet, which has been marketed since 1992. The packages of Asacol ${ }^{\circledR}$ and Asacol HD ${ }^{\circledR}$ carried the notice, that both are not bioequivalent to each other. In the same year, Proctor and Gamble sold the Asacol ${ }^{\circledR}$ franchise to Warner-Chilcott (Rockaway, NJ, USA). The sales of Asa$\mathrm{col}^{\circledR}$, which was the market leader, with a $52 \%$ share of the US oral 5-ASA market in 2008, were slowly eroding over the years (Table 3, column 9). Meanwhile the production of Asacol ${ }^{\circledR}$ was discontinued in the US market by Warner and Chilcott and substituted by the launch of Delzicol ${ }^{\circledR}$ in March 2013. Delzicol ${ }^{\circledR}$ offers $400 \mathrm{mg}$ of mesalamine as an easier to swallow capsule instead of the tablet. Patents are supposed to protect Delzicol ${ }^{\circledR}$ until 2020; however, it was not granted a 3 -year new drug product exclusivity, limiting the protection in the marketplace. Investors and shareholders are consoled that generic competition for the company's mesalamine-based UC franchise $\left(\right.$ Asacol $^{\circledR}$, Asacol HD $^{\circledR}$, and Delzicol ${ }^{\circledR}$ ) remains highly unlikely over the next few years, given the challenging pathway to approval. ${ }^{74}$

\section{Competition through new products}

Even more competition in the 5-ASA market arrived with the "new kid on the block" in the form of Shire's products Lialda $^{\circledR}$ for the US market and Mezavant ${ }^{\circledR}$ for the European market. Lialda ${ }^{\circledR}$ was launched in March 2007, and Mezavant ${ }^{\mathbb{B}}$ 
Table 2 Market shares of oral 5-aminosalicylic products in the 2010 and 2011 European market ${ }^{70}$

\begin{tabular}{|c|c|c|c|c|c|c|c|c|c|c|c|}
\hline \multirow[t]{4}{*}{ Product } & \multirow[t]{4}{*}{ Manufacturer } & \multicolumn{10}{|c|}{ Market share, \% } \\
\hline & & \multicolumn{2}{|l|}{ UK } & \multicolumn{2}{|c|}{ Germany } & \multicolumn{2}{|c|}{ Spain } & \multicolumn{2}{|c|}{ France } & \multirow{2}{*}{\multicolumn{2}{|c|}{$\begin{array}{l}\text { EU5 (UK, Germany } \\
\text { Spain, France, Italy) }\end{array}$}} \\
\hline & & \multirow[t]{2}{*}{2010} & \multirow[t]{2}{*}{2011} & \multirow[t]{2}{*}{2010} & \multirow[t]{2}{*}{2011} & \multirow[t]{2}{*}{2010} & \multirow[t]{2}{*}{2011} & \multirow[t]{2}{*}{2010} & \multirow[t]{2}{*}{2011} & & \\
\hline & & & & & & & & & & 2010 & 2011 \\
\hline Asacol $^{\circledR}$ & Warner-Chilcott & 56 & 45.8 & & & & & & & 21 & 19 \\
\hline Salofalk ${ }^{\circledR}$ & Dr Falk & & & 56 & 53.2 & & & & & & \\
\hline Mezavant ${ }^{\circledR}$ & Shire & & & 17 & & & & & & & \\
\hline Pentasa $^{\circledR}$ & Ferring & 25 & 27.1 & & 18 & 46 & 35.2 & 78 & & & 29.6 \\
\hline Claversal $^{\circledR}$ & Recordati & & & 15 & & 41 & 29.3 & & & & \\
\hline Fivasa $^{\circledR}$ & Norgine BV & & & & & & & 19 & & & \\
\hline
\end{tabular}

started in the UK in November 2007. Lialda's ${ }^{\circledR}$ share of the US oral mesalamine market jumped from $3.9 \%$ in 2007 to $20 \%$ in 2009 , the combined worldwide revenue for Lialda ${ }^{\circledR}$ and Mezavant ${ }^{\circledR}$ reached in 2012, with US\$400 million, eight times the level of 2007 (Table 3, columns 1 and 4). Meanwhile the market share of Pentasa ${ }^{\circledR}$, which is also marketed by Shire in the US, dropped continuously (Table 3, column 6). The revenue for Pentasa ${ }^{\circledR}$ still grew continuously, despite lower prescription demand due to the impact of price increases (Table 3, column 7).$^{70}$ As mentioned above, the US market leader Asacol ${ }^{\circledR}$ also lost market share in the years following the launch of Lialda ${ }^{\circledR}$. A decrease in prescriptions was offset in net sales (US\$793 million for 2012) by higher selling prices and a decrease in sales-related deductions. ${ }^{75}$ In May 2013, Watson Pharmaceuticals (now Actavis plc; Dublin, Ireland) sought approval from the FDA to market a generic version of Lialda ${ }^{\circledR}$. The Southern District Court of Florida, however, upheld the validity of the patent covering Lialda $^{\circledR}$ until it expires in 2020.

\section{OD dosing: randomized controlled trials}

From 2007 on, a series of randomized studies were published dealing with the comparison of OD and conventional dosing for maintenance and induction of remission. The critical questions to be answered are as follows: What is the efficacy of OD dosing compared with conventional dosing? In the case that OD dosing is more efficient, is this because of better adherence or because of other reasons? Does OD dosing lead to more adverse events compared with conventional dosing?

\section{OD dosing in maintenance of remission}

Ford and coauthors published a meta-analysis on OD dosing versus a conventional dosing schedule of 5-ASA in maintenance of remission in 2011.63 They identified seven eligible randomized controlled trials (RCTs) comprising a total of 2,745 patients. ${ }^{47,65,76-80}$ Five RCTs compared OD with BID dosing, and two compared OD with TID. The drugs used in the studies were $\operatorname{Asacol}^{\circledR}(4 \times), \operatorname{MMX}(2 \times)$, Pentasa $^{\circledR}(1 \times)$, and Salofalk $^{\circledR}(1 \times)$. Duration of treatment and follow-up was 12 months in all studies.

Relapse rates were not significantly different between OD and conventional dosing schedules for 5-ASA, with $423(31.4 \%)$ versus 461 (33.0\%) patients relapsing, respectively (relative risk [RR] of relapse $0.94 ; 95 \%$ CI 0.82-1.08). ${ }^{63}$

Four trials with 994 patients could be analyzed for noncompliance. Definitions of compliance in these trials

Table 3 Market share and revenue reached by Shire’s products Lialda ${ }^{\circledR}$ and Mezavant ${ }^{\circledR}$ in comparison with Pentasa ${ }^{\circledR}$ and Asacol ${ }^{\circledR 70}$

\begin{tabular}{|c|c|c|c|c|c|c|c|c|c|}
\hline \multirow[t]{2}{*}{ Year } & I & 2 & 3 & $4(=2+3)$ & 5 & 6 & 7 & $8(=I+6)$ & 9 \\
\hline & $\begin{array}{l}\text { Lialda }^{\circledR} \\
\text { US oral } \\
\text { mesalamine } \\
\text { market } \\
\text { share, \% }\end{array}$ & $\begin{array}{l}\text { Lialda }^{\circledR} \\
\text { US oral } \\
\text { mesalamine } \\
\text { revenue, } \\
\text { million USD }\end{array}$ & $\begin{array}{l}\text { Mezavant }^{\circledR} \\
\text { Europe oral } \\
\text { mesalamine } \\
\text { revenue, } \\
\text { million USD }\end{array}$ & $\begin{array}{l}\text { Lialda }^{\circledR}+ \\
\text { Mezavant }^{\circledR} \\
\text { worldwide } \\
\text { revenue, } \\
\text { million USD }\end{array}$ & $\begin{array}{l}\text { Lialda }^{\circledR} \\
\text { total } \\
\text { US UC } \\
\text { market } \\
\text { share, \% }\end{array}$ & $\begin{array}{l}\text { Pentasa }^{\circledR} \\
\text { US oral } \\
\text { mesalamine } \\
\text { market } \\
\text { share, \% }\end{array}$ & $\begin{array}{l}\text { Pentasa }^{\circledR} \\
\text { US market } \\
\text { revenue, } \\
\text { million } \\
\text { USD }\end{array}$ & $\begin{array}{l}\text { Shire US oral } \\
\text { mesalamine } \\
\text { market share } \\
\left(\text { Lialda }^{\circledR}+\right. \\
\left.\text { Pentasa }^{\circledR}\right), \%\end{array}$ & $\begin{array}{l}\text { Asacol }^{\circledR} \\
\text { US oral } \\
\text { mesalamine } \\
\text { market } \\
\text { share, \% }\end{array}$ \\
\hline 2007 & 3.9 & 50.3 & 0.2 & 50.5 & & 17.2 & 176.4 & 21.1 & \\
\hline 2008 & 11.7 & 134.8 & 5.6 & 140.4 & $18 \%$ & 16.7 & 185.5 & 28.4 & 52.3 \\
\hline 2009 & 20.0 & & & 235.9 & & 12.0 & 214.8 & 32.0 & 42.4 \\
\hline 2010 & & & & 293.4 & & & 235.9 & 34.5 & 37.4 \\
\hline 2011 & & & & 372.1 & & & 251.1 & 35.8 & \\
\hline 2012 & & & & 399.9 & & & 265.8 & & \\
\hline
\end{tabular}

Abbreviation: UC, ulcerative colitis; USD, US dollars. 
included taking between $75 \%$ and $90 \%$ or more of the study medication, according to self-report. There was no significant difference in compliance, as 43 (8.8\%) and 52 (10.3\%) patients in the OD and the conventional dosing group were classed as being noncompliant $(\mathrm{RR}$ of noncompliance $=0.87$ (95\% CI 0.46-1.66). The failure to demonstrate better adherence in the OD arm was explained with the very high adherence rate of about $90 \%$. This high rate is thought to mirror the high motivation of patients participating in RCTs and unlikely to be representative of patients seen in the real world. ${ }^{63}$ The result was especially disappointing, since poor adherence was thought to be particularly problematic in quiescent disease.

Finally, five trials comprising 1,356 patients provided data concerning total adverse events, but there were insufficient data regarding individual adverse events. Again, there was no statistically significant difference between adverse events in the OD arm $(332 ; 50 \%)$ and the conventional dosing arm (320; 46.2\%) resulting in an RR for experiencing any adverse event in the OD group $=1.08$ (95\% CI 0.97-1.20) ${ }^{63}$

In summary, patients with UC in remission can be switched to an OD dosing schedule without compromising efficacy and safety. Outside of clinical trials, OD dosing may lead to enhanced drug adherence.

\section{OD dosing in induction of remission}

$\mathrm{Up}$ to this point, there were four RCTs on the comparison of OD dosing with conventional dosing in induction of remission, ${ }^{69,81-83}$ three of which were summarized in the metaanalysis by Feagan and MacDonald. ${ }^{84}$ The study by Flourie et $\mathrm{al}^{83}$ published in 2013 was not included. The characteristics of those studies are summarized in Table 4.

The study of Lichtenstein et $\mathrm{al}^{81}$ compared MMX 5-ASA $2.4 \mathrm{~g}$ BID, $4.8 \mathrm{~g}$ MMX 5-ASA OD or placebo for 8 weeks in patients with mild to moderately active UC. The primary endpoint was the percentage of patients in clinical and endoscopic remission at week 8 (UC-Disease Activity Index (DAI) score $\leq 1$ ). This endpoint was achieved by $34.1 \%$ and $29.2 \%$ of patients receiving MMX 5-ASA $2.4 \mathrm{~g}$ BID and MMX $4.8 \mathrm{~g} /$ day OD, respectively, versus $12.9 \%$ receiving placebo $(P<0.01)$. There was no significant difference between the MMX 5-ASA groups.

According to the double-blind, double-dummy design of this study performed between 2003 and 2005, each patient received medication BID. Therefore, the hypothesis of better adherence with OD dosing was not addressed. Adherence was similar in all the treatment groups. Ninety percent of patients in the safety population took between $80 \%$ and $120 \%$ of the study medication.

Both doses of MMX 5-ASA (2.4 g BID and $4.8 \mathrm{~g}$ OD) were well tolerated in this study, with a safety profile similar to other 5-ASA formulations. There was no evidence of a dose-response relationship for any safety parameter, and no clinically significant differences in safety were observed between placebo and either dose of MMX 5-ASA. ${ }^{81}$

The study by Kamm et $\mathrm{al}^{69}$ was conducted in 2003 and 2004. Patients with active, mild-to-moderate UC received

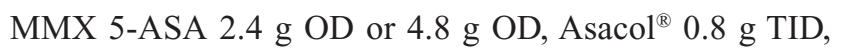
or placebo for 8 weeks. The primary endpoint was the proportion of patients in clinical and endoscopic remission

Table 4 Characteristics of randomized controlled trials of once-daily dosing versus conventional dosing in induction of remission in ulcerative colitis patients

\begin{tabular}{|c|c|c|c|c|c|c|}
\hline Study & Year & $\begin{array}{l}\text { Number of } \\
\text { patients }\end{array}$ & $\begin{array}{l}\text { Country, number } \\
\text { of centers }\end{array}$ & Intervention & $\begin{array}{l}\text { Duration } \\
\text { of therapy }\end{array}$ & Methodology \\
\hline $\begin{array}{l}\text { Lichtenstein } \\
\text { et } \mathrm{a}^{81}\end{array}$ & 2007 & 280 & $\begin{array}{l}\text { Eight countries, } \\
52 \text { centers }\end{array}$ & $\begin{array}{l}4.8 \mathrm{mg} \text { MMX OD }(n=94) \\
2.4 \mathrm{mg} \text { MMX BID }(n=93) \\
\text { Placebo }(n=93)\end{array}$ & 8 weeks & $\begin{array}{l}\text { Double-blind } \\
\text { Double-dummy }\end{array}$ \\
\hline $\begin{array}{l}\text { Kamm } \\
\text { et } \mathrm{al}^{69}\end{array}$ & 2007 & 341 & $\begin{array}{l}\text { Ten countries, } \\
49 \text { centers }\end{array}$ & $\begin{array}{l}2.4 \mathrm{mg} \text { MMX OD }(n=84) \\
4.8 \mathrm{mg} \text { MMX OD }(n=86) \\
800 \mathrm{mg} \text { Asacol }{ }^{\circledR} \text { TID }(n=86) \\
\text { Placebo }(n=86)\end{array}$ & 8 weeks & $\begin{array}{l}\text { Double-blind } \\
\text { Double-dummy }\end{array}$ \\
\hline Kruis et $\mathrm{al}^{82}$ & 2009 & 380 & $\begin{array}{l}\text { I } 3 \text { countries, } \\
54 \text { centers }\end{array}$ & $\begin{array}{l}3 \text { g Salofalk }{ }^{\circledR} \text { OD }(n=191) \\
\text { I g Salofalk }{ }^{\circledR} \text { TID }(n=189)\end{array}$ & 8 weeks & $\begin{array}{l}\text { Double-blind } \\
\text { Double-dummy } \\
\text { Non-inferiority }\end{array}$ \\
\hline $\begin{array}{l}\text { Flourie } \\
\text { et } \mathrm{al}^{83}\end{array}$ & 2013 & 206 & $\begin{array}{l}\text { Four countries, } \\
44 \text { centers }\end{array}$ & $\begin{array}{l}4 \text { g Pentasa }{ }^{\circledR} \text { OD }(n=102) \\
+ \text { I g } 5-A S A \text { enema } \\
2 \text { g Pentasa }{ }^{\circledR} \text { BID }(n=104) \\
+ \text { I g } 5-A S A \text { enema }\end{array}$ & $\begin{array}{l}8 \text { weeks } \\
\text { Enema: } \\
4 \text { weeks }\end{array}$ & $\begin{array}{l}\text { Single-blind } \\
\text { Non-inferiority }\end{array}$ \\
\hline
\end{tabular}

Note: Copyright @ 2012. John Wiley \& Sons Ltd. Adapted from Feagan BG, MacDonald JK. Once daily oral mesalamine compared to conventional dosing for induction and maintenance of remission in ulcerative colitis: a systematic review and meta-analysis. Inflamm Bowel Dis. 2012;18:1785-I794. ${ }^{84}$

Abbreviations: MMX, multi-matrix; OD, once daily; BID, twice a day; TID, three times a day. 
(UC-DAI $\leq 1)$. In the intention-to-treat (ITT) population, a statistically significantly greater proportion of patients receiving MMX 5-ASA $2.4 \mathrm{~g}$ OD (40.5\%; $P=0.010)$ or $4.8 \mathrm{~g}$ OD $(41.2 \% ; P=0.007)$ achieved clinical and endoscopic remission compared with placebo $(22.1 \%)$. The proportion of patients receiving Asacol ${ }^{\circledR} 0.8 \mathrm{~g}$ TID who achieved clinical and endoscopic remission was not statistically significantly greater than placebo $(32.6 \% ; P=0.124)$. In the subgroup analysis of the ITT population, including patients with mild or moderate disease at baseline and patients with left-sided or extensive disease, remission rates (clinical and endoscopic) were not statistically significantly greater for either dose of MMX mesalamine or Asacol ${ }^{\circledR}$ than for placebo. This was felt to be due to the limited patient numbers.

Similar to the study by Lichtenstein et al, ${ }^{81}$ every patient received medication three times a day because of the doubleblind, double-dummy study design. Therefore, adherence according to the dosing scheme could not be evaluated. More than $92 \%$ of patients in each treatment group took between $80 \%$ and $120 \%$ of the study medication.

There were no notable differences between the treatment groups with respect to the frequency of treatment-emergent adverse events, and there was no evidence of a dose-response relationship with MMX 5-ASA for any safety parameter. Hepatobiliary, renal, and urinary adverse events were very infrequent. ${ }^{69}$

In the study by Kruis et al, ${ }^{82} 380$ patients with confirmed diagnosis of UC (either established or first attack) with a clinical activity index $>4$ and endoscopic index $\geq 4$ at baseline were randomized and treated with either $3 \mathrm{~g}$ OD or $1 \mathrm{~g}$ TID of Salofalk ${ }^{\circledR}$ 5-ASA granules. The primary endpoint was the percentage of patients achieving clinical remission defined as a clinical activity index $\leq 4$ at the end of the study. In the ITT population, clinical remission was achieved by $151 / 191$ patients (79.1\%) in the OD group and $143 / 189$ patients $(75.7 \%)$ in the TID group, demonstrating non-inferiority between the OD and TID group, with a highly significant $P$-value of $0.0001 .^{82}$

Endoscopic remission using the endoscopic index was obtained in $135 / 191$ patients $(71 \%)$ in the OD group and $132 / 189(70 \%)$ in the TID group at the end of the study (ITT). There was no statistically significant difference between the groups.

In the subgroup analysis within the OD group, significantly more patients with mild as compared with moderate disease achieved clinical remission (85\% versus $69 \%$; $P=0.0067)$. Disease localization also had an impact on the remission rates achieved. Whereas no significant difference in proximal disease (ie, left-sided, subtotal, and pancolitis) was observed between the OD and TID groups, there was a significant difference in distal disease between the groups ( $86 \%$ versus $73 \% ; P=0.0298$ ) as well as within the OD group itself between distal and proximal disease ( $86 \%$ versus $72 \%$; $P=0.0247$ ). A pooled analysis also suggested higher efficacy in distal disease for 5-ASA granules administered OD in comparison with 5-ASA tablets TID, ${ }^{85}$ although the conclusion was questioned by others due to the heterogeneity of the pooled studies. ${ }^{86}$

In a post hoc analysis, the efficacy data from the study by Kruis et al $^{82}$ were recalculated using a more stringent definition of remission used in the MMX 5-ASA trials. In this analysis of the ITT population, 70/191 patients (37\%) in the OD group and 73/189 (39\%) in the TID group achieved remission. These numbers are nearly identical to those reported in a pooled analysis ${ }^{87}$ of the two trials discussed above, ${ }^{69,81}$ with remission rates of 64/172 (37\%) for $2.4 \mathrm{~g}$ MMX 5-ASA OD and 61/174 (35\%) for $4.8 \mathrm{~g}$ MMX 5-ASA OD.

Again the double-blind, double-dummy design precluded an analysis of medication adherence depending on the schedule. However, asked which dosing schedule they prefer, the vast majority of patients $313 / 380(82 \%)$ favored an OD dosing regimen; only $6 / 380$ patients $(2 \%)$ preferred the TID schedule, and 55/380 (14\%) had no preference. ${ }^{82}$

Treatment with the study medication was well tolerated, and there was no difference in the occurrence of adverse events between the two dosing regimens. The majority of adverse events were mild or moderate in intensity, and no unexpected side effects occurred. Special emphasis had been put on potential adverse effects on renal function. Urinary function tests using sensitive early markers of renal disease ( $\alpha 1$-microglobulin, $\beta$-N-acetyl-D-glucosaminidase ( $\beta-N A G)$, and cystatin $C$ ) showed no impairment of renal function, and indicated that an oral OD dose of $3 \mathrm{~g}$ mesalazine, which may be associated with higher peak plasma levels as compared with a $1 \mathrm{~g}$ TID regimen, is at least as safe as a $1 \mathrm{~g}$ TID dose with regard to potential tubulo-toxicity. ${ }^{82}$

The meta-analysis of Feagan and MacDonald ${ }^{84}$ pooled the three trials discussed above with 738 patients. ${ }^{69,81,82}$ Of the patients in the OD dosing group, 42\% (155/370) failed to enter remission compared with $44.3 \%$ (163/368) of patients in the conventional dosing group. The pooled RR was 0.95 (95\% CI 0.82-1.10), demonstrating no statistically significant difference between OD dosing and conventional dosing $(P=0.49)$. Furthermore, none of the subgroup comparisons by formulation showed any differences in efficacy between OD dosing and conventional dosing. ${ }^{84}$ 
Finally, the study by Flourie et $\mathrm{al}^{83}$ randomized 206 patients with mild-to-moderately active UC to 8 weeks of $4 \mathrm{~g}$ Pentasa ${ }^{\circledR}$ OD or $2 \mathrm{~g}$ BID. Patients additionally received a $1 \mathrm{~g} 5$-ASA enema per day for 4 weeks. The primary endpoint was the percentage of patients in clinical and endoscopic remission after 8 weeks (defined as UC-DAI score $\leq 1$ ). Although recruiting fell short of the goal, the primary endpoint was reached, and non-inferiority of OD versus BID dosing was demonstrated with $52.1 \%$ of patients in the ITT OD group and $41.8 \%$ of patients in the BD group in clinical and endoscopic remission at week $8 .{ }^{83}$

As this study was only investigator-blinded, an evaluation of acceptability and compliance for the two dosing schedules could be done. Acceptability using a visual analog scale was numerically but not statistically higher at week 8 for the OD arm compared with the BID arm (OD $73.2 \% \pm 22.3 \%$ versus BID $66.3 \% \pm 29.4 \% ; P=0.10$ ). Compliance was high, with median compliance rates of $100 \%$ in both treatment arms.

There were no differences in adverse events, laboratory results, or vital signs between the two study groups ${ }^{83}$

In summary, available RCTs demonstrated consistently, the following: ${ }^{84}$

- 5-ASA administration OD is as effective as conventional dosing for induction therapy in mild to moderate active UC.

- Subgroup analysis by drug formulation showed no differences in efficacy between OD and conventional dosing for induction of remission. 5-ASA formulations employed for OD dosing are MMX, Salofalk ${ }^{\circledR}$, and Pentasa ${ }^{\circledR}$.

- No differences regarding safety outcomes were detected between OD and conventional dosing, including incidence of adverse events, serious adverse events, or withdrawal from treatment due to an adverse event.

- OD dosing did not lead to superior efficacy, although three out of four studies showed a trend in this sense. Due to the study design, dosing-dependent adherence could not be evaluated in three of four studies. In the study by Flourie et al ${ }^{83}$ there was no difference in adherence between the OD and the BID group. In the study by Kruis et $\mathrm{a}^{82}$ that measured patient preference, the majority preferred OD dosing to conventional dosing; in the study by Flourie et $a 1,{ }^{83}$ the preference for OD dosing was not statistically significant. Overall, it is felt that it may be difficult to detect differences in adherence between OD and multiple-dose regimens in the clinical trial setting because of the adherence rates beyond $90 \%$. To examine this issue further, large-scale community-based studies are suggested, although they should be most promising in the maintenance of remission situation.

To this end, several Shire-sponsored studies have been published suggesting an advantage of OD MMX 5-ASA over other 5-ASA formulations regarding adherence and persistency ${ }^{88-90}$ However, these studies harbor several limitations regarding the collection and interpretation of the data. Furthermore, 5-ASA formulations approved for OD dosing other than MMX were not considered. Overall, there remain doubts about the size of the contribution OD dosing can make to a better drug adherence. . $^{79,84,91}$

\section{Safety}

In 1991, Hayllar and Bjarnason ${ }^{64}$ argued for a continued role of SASP in the treatment of UC, also warning against 5-ASA toxicity due to the altered pharmacokinetics in comparison to SASP, which may lead to nephrotoxicity among others. In 2002, Ransford and Langman ${ }^{92}$ stirred up the scientific and clinical community with their comparison of reported serious adverse advents between SASP and 5-ASA. With a total of 4.7 million prescriptions evaluated for SASP compared with 2.8 million for 5-ASA, interstitial nephritis was only described for 5-ASA, with 11.1 reports per million prescriptions, and pancreatitis was reported seven times as frequently for 5-ASA (7.5 per million prescriptions) compared with SASP (1.1 per million prescriptions). In contrast, there were more serious adverse events reported for SASP regarding blood dyscrasias and hepatic disorders than for 5-ASA. ${ }^{92}$ The authors came to the conclusion that there is no evidence to indicate a safety advantage of 5-ASA over SASP in the treatment of inflammatory bowel disease and that advice on renal monitoring in patients who receive 5-ASA may need reinforcing. The study was soundly criticized by others on several accounts. ${ }^{93}$

Meanwhile, numerous studies and systematic reviews demonstrate that 5-ASA has an adverse event profile and is frequency similar to placebo with intolerance occurring in up to $15 \%$. No differences between different 5-ASA formulations can be detected. Diarrhea (3\%), headache (2\%), nausea $(2 \%)$, rash $(1 \%)$ and thrombocytopenia $(<1 \%)$ are reported. $4,22,48,94,95$

In particular, meta-analyses suggest that there is no difference in safety between OD and conventionally dosed mesalamine. No differences have been observed for safety outcomes including the overall incidence of adverse events or withdrawal from treatment due to an adverse event. Adverse events reported in the studies assessing OD dosing are mild to moderate in intensity and include gastrointestinal symp- 
toms (eg, flatulence, abdominal pain, nausea, and diarrhea), headache, and worsening UC. ${ }^{48,63,84}$

\section{Nephrotoxicity}

Among idiosyncratic reactions attributed to 5-ASA nephrotoxicity remains the most debated. ${ }^{96,97}$ A continued issue remains the potential nephrotoxicity of 5-ASA and the measures to be taken to avoid an affection of the kidney function.

Gisbert et $\mathrm{al}^{98}$ summarized the current knowledge about the potential relationship between 5-ASA treatment and nephrotoxicity. They found that renal impairment in IBD patients may be partly attributable to the underlying disease, although users of 5-ASA may have an increased risk of renal disease. Epidemiological studies evaluating nephrotoxicity in IBD patients treated with 5-ASA suggest the incidence to be less than $0.5 \%$. 5-ASA treatment-related nephrotoxicity is reported most often within the first 12 months, but also delayed presentation after several years has been observed. Nephrotoxicity is unlikely to be detected by urinalysis (eg, leukocyturia and low-grade proteinuria), therefore emphasizing the importance of monitoring serum creatinine in patients with IBD treated with 5-ASA. The low overall incidence of renal disease during 5-ASA treatment reported in the literature, and the absence of a clear relationship between 5-ASA dose and the risk of nephrotoxicity, suggest that the renal reactions may be idiosyncratic rather than dose-related in nature. 5-ASA-associated nephrotoxicity most frequently takes the form of an indolent, severe, chronic, and progressive interstitial nephritis. The nephrotoxicity potential of mesalazine and SASP seems to be similar; potential differences in the relative risk with different oral preparations of 5-ASA are probably too small to influence the choice of agent. Although data in the literature about the safety of 5-ASA compounds in patients with IBD and chronic renal failure are lacking, there needs to be more attention and scrutiny for those patients.

In a patient with IBD in whom no other cause can be readily identified for renal impairment, 5-ASA should be discontinued. If withdrawal of 5-ASA treatment does not result in a fall in serum creatinine, then the patient should be referred for renal biopsy, as only this will determine whether interstitial nephritis or glomerulonephritis associated with IBD is the cause of the persistent impaired renal function. Although the data are ambiguous, a trial of high-dose steroid ( $60 \mathrm{mg}$ /day or $1 \mathrm{mg}$ day/ $\mathrm{kg}$ for up to 3 months) has been suggested in patients whose renal function does not respond to drug withdrawal alone.

It has been calculated that approximately $10 \%$ of the patients with 5-ASA nephrotoxicity will develop end-stage renal disease, emphasizing the need for timely recognition of renal impairment and prompt discontinuation of 5-ASA treatment of affected patients. Thus, many authors agree on performing a monitoring of renal function by serum creatinine measurements, although the optimal monitoring schedule remains to be established, and there is presently no evidence that such screening or monitoring improves patient outcomes. ${ }^{4,22,98}$

A recent study with the largest collection of patients $(n=156)$ with suspected 5-ASA-related nephrotoxicity in IBD patients emphasizes some of the points made above. ${ }^{99}$ The adverse effect was seen with all aminosalicylates (mesalazine, balsalazide, olsalazine, and SASP). The first abnormal blood test occurred in $22.4 \%$ of patients within the first 12 months after introduction of 5-ASA. After drug withdrawal, $81.1 \%$ had a recovery of renal function, 17 patients required renal replacement therapy, including 15 with kidney transplantation. The study includes genomewide association analysis and subsequent sequencing to identify clinically useful predictive genetic markers so that these drugs can be either avoided or monitoring intensified in high-risk patients. ${ }^{99}$

\section{Disclosure}

The authors report no conflicts of interest in this work.

\section{References}

1. Ham M, Moss AC. Mesalamine in the treatment and maintenance of remission of ulcerative colitis. Expert Rev Clin Pharmacol. 2012;5:113-123.

2. Loftus EV. Clinical epidemiology of inflammatory bowel disease: incidence, prevalence, and environmental influences. Gastroenterology. 2004;126:1504-1517.

3. Lakatos PL. Recent trends in the epidemiology of inflammatory bowel diseases: up or down? World J Gastroenterol. 2006;12:6102-6108.

4. Dignass A, Lindsay JO, Sturm A, et al. Second European evidencebased consensus on the diagnosis and management of ulcerative colitis: current management. J Crohns Colitis. 2012;6:991-1030.

5. Dignass A, Preiss JC, Aust DE, et al. [Updated German guideline on diagnosis and treatment of ulcerative colitis, 2011]. Z Gastroenterol. 2011;49:1276-1341. German.

6. Kornbluth A, Sachar DB. Ulcerative colitis practice guidelines in adults. American College of Gastroenterology, Practice Parameters Committee. Am J Gastroenterol. 2010;105:501-523.

7. Svartz N. Salazopyrin, a new sulfanilamide preparation: A. Therapeutic results in rheumatic polyarthritis. B. Therapeutic results in ulcerative colitis. C. Toxic manifestations in treatment with sulfanilamide preparation. Acta Med Scand. 1942;11:557-590.

8. Sutherland L, MacDonald JK. Oral 5-aminosalicylic acid for induction of remission in ulcerative colitis. Cochrane Database Syst Rev. 2006;2:CD000543.

9. Azad Kahn AK, Piris J, Truelove SC. An experiment to determine the active therapeutic moiety of sulphasalazine. Lancet. 1977;310:892-895.

10. van Hees PA, Bakker JH, van Tongeren JH. Effect of sulphapyridine, 5-aminosalicyclic acid, and placebo in patients with idiopathic proctitis: a study to determine the active therapeutic moiety of sulphasalazine. Gut. 1980;21:632-635. 
11. Klotz U, Maier K, Fischer C, et al. Therapeutic efficacy of sulfasalazine and its metabolites in patients with ulcerative colitis and Crohn's disease. N Engl Med J. 1980;303:1499-1502.

12. Nielsen $\mathrm{OH}$. Sulfasalzine intolerance. A retrospective survey of the reasons for discontinuing treatment with sulfasalazine in patients with chronic inflammatory bowel disease. Scand J Gastroenterol. 1982;17:389-393.

13. Peppercorn MA. Sulfasalazine. Pharmacology, clinical use, toxicity, and related new drug development. Ann Intern Med. 1984;101:377-386.

14. Nielsen $\mathrm{OH}$, Bondesen $\mathrm{S}$. Kinetics of 5-aminosalicylic acid after jejunal instillation in man. Br J Clin Pharmacol. 1983;16:738-740.

15. Myers B, Evans DN, Rhodes J, et al. Metabolism and urinary excretion of 5-aminosalicylic acid in healthy volunteers when given intravenously or released for absorption at different sites in the gastrointestinal tract Gut. 1987;28:196-200.

16. Sandborn WJ, Hanauer SB. Systematic review: the pharmacokinetic profiles of oral mesalazine formulations and mesalazine pro-drugs used in the management of ulcerative colitis. Aliment Pharmacol Ther. 2003; 17:29-42.

17. Sandborn WJ. Oral 5-ASA therapy in ulcerative colitis: what are the implications of the new formulations? J Clin Gastroenterol. 2008;42:338-344.

18. Egan LJ, Mays DC, Huntoon CJ, et al. Inhibition of interleukin-1stimulated NF-kappaB RelA/p65 phosphorylation by mesalamine is accompanied by decreased transcriptional activity. J Biol Chem. 1999;274:26448-26453.

19. Liptay S, Bachem M, Hacker G, et al. Inhibition of nuclear factor $\kappa B$ and induction of apoptosis in T-lymphocytes by sulfasalazine. $\mathrm{Br} J$ Pharmacol. 1999;128:1361-1369.

20. Bantel H, Berg C, Vieth $M$ et al. Mesalazine inhibits activation of transcription factor NF-kappaB in inflamed mucosa of patients with ulcerative colitis. Am J Gastroenterol. 2000;95:3452-3457.

21. Desreumaux P, Ghosh S. Review article: mode of action and delivery of 5-aminosalicylic acid - new evidence. Aliment Pharm Ther. 2006; 24(Suppl 1):2-9.

22. Klotz U. The pharmacological profile and clinical use of mesalazine (5-aminosalicylic acid). Arzneimittelforschung. 2012;62:53-58.

23. Desreumaux P. Understanding the mechanism of 5-ASA in treating colonic inflammation. Gastroenterol Hepatol. 2008;4:319-320.

24. Bertin B, Dubuquoy L, Colombel JF, Desreumaux P. PPAR-gamma in ulcerative colitis: a novel target for intervention. Curr Drug Targets. 2013;14:1501-1507.

25. Lichtenstein GR, Kamm MA. Review article: 5-aminosalicylate formulations for the treatment of ulcerative colitis - methods of comparing release rates and delivery of 5-aminosalicylate to the colonic mucosa. Aliment Pharmacol Ther. 2008;28:663-673.

26. Campieri M, Lanfranchi GA, Bazzocchi G, et al. Treatment of ulcerative colitis with high-dose 5-aminosalicylic acid enemas. Lancet. 1981;2(8241):270-271.

27. Harris MS, Lichtenstein GR. Review article: delivery and efficacy of topical 5-aminosalicylic acid (mesalazine) therapy in the treatment of ulcerative colitis. Aliment Pharmacol Ther. 2011;33:996-1009.

28. Ford AC, Khan KJ, Achkar JP, et al. Efficacy of oral vs topical, or combined oral and topical 5-aminosalicylates, in ulcerative colitis: systematic review and meta-analysis. Am J Gastroenterol. 2012;107: 167-176.

29. Campieri M, Corbelli C, Gionchetti P, et al. Spread and distribution of 5-ASA colonic foam and 5-ASA enema in patients with ulcerative colitis. Dig Dis Sci. 1992;37:1890-1897.

30. Ghosh S, Shand A, Ferguson A. Ulcerative colitis. BMJ. 2000;320: 1119-1123.

31. Seibold F, Fournier N, Beglinger C, et al. Swiss IBD cohort study group. Topical therapy is underused in patients with ulcerative colitis. J Crohns Colitis. 2014;8:56-63.

32. Farrell RJ, Peppercorn MA. Equimolar doses of balsalazide and mesalamine: are we comparing apples and oranges? Am J Gastroenterol. 2002;97:1283-1285.
33. Forbes A, Cartwright A, Marchant S, McIntyre P, Newton M. Review article: Oral, modified-release mesalazine formulations - proprietary versus generic. Aliment Pharmacol Ther. 2003;17:1207-1214.

34. Wilding IR, Kenyon CJ, Hooper G. Gastroinestinal spread of oral prolonged-release mesalazine microgranules (Pentasa) dosed as either tablets or sachet. Aliment Pharmacol Ther. 2000;14:163-169.

35. Farup PG, Hinterleitner TA, Lukas M, et al. Mesalazine $4 \mathrm{~g}$ daily given as prolonged-release granules twice daily and four times daily is at least as effective as prolonged-release tablets four times daily in patients with ulcerative colitis. Inflamm Bowel Dis. 2001;7:237-242.

36. Kruis W, Klugmann T, Duffelmeyer C, et al. Detailed analysis of factors determining patients adherence to therapy in ulcerative colitis. UEGJ. 2013;1(Suppl 1):A224 (P342).

37. Forbes A, Al-Damluji A, Ashworth S, et al. Multicentre randomizedcontrolled clinical trial of Ipocol, a new enteric-coated form of mesalazine, in comparison with Asacol in the treatment of ulcerative colitis. Aliment Pharmacol Ther. 2005;21:1099-1104.

38. Wilding IR, Behrens C, Tardif SJ, et al. Combined scintigraphic and pharmacokinetic investigation of enteric-coated mesalazine micropellets in healthy subjects. Aliment Pharmacol Ther. 2003;17:1153-1162.

39. Raedler A, Behrens C, Bias P. Mesalazine (5-aminosalicylic acid) micropellets show similar efficacy and tolerability to mesalazine tablets in patients with ulcerative colitis - results from a randomized-controlled trial. Aliment Pharmacol Ther. 2004;20:1353-1363.

40. Brunner M, Greinwald R, Kletter K, et al. Gastrointestinal transit and release of 5-aminosalicylic acid from $153 \mathrm{Sm}$-labelled mesalazine pellets vs tablets in male healthy volunteers. Aliment Pharmacol Ther. 2003; 17:1163-1169.

41. Kruis W, Bar-Meir S, Feher J, et al. The optimal dose of 5-aminosalicylic acid in active ulcerative colitis: a dose-finding study with newly developed mesalamine. Clin Gastroenterol Hepatol. 2003;1:36-43.

42. Lakatos PL. Use of new once-daily 5-aminosalicylic acid preparations in the treatment of ulcerative colitis: is there anything new under the sun? World J Gastroenerol. 2009;15:1799-1804.

43. Brunner M, Assandri R, Kletter K, et al. Gastrointestinal transit and 5-ASA release from a new mesalazine extended-release formulation. Aliment Pharmacol Ther. 2003;17:395-402.

44. Prantera C, Viscido A, Biancone L, et al. A new oral delivery system for 5-ASA: preliminary clinical findings for MMX. Inflamm Bowel Dis. 2005; 11:421-427.

45. Sutherland L, MacDonald JK. Oral 5-aminosalicylic acid for maintenance of remission in ulcerative colitis. Cochrane Database Syst Rev. 2006;2:CD000544.

46. Ito H, Iida M, Matsumoto T, et al. Direct comparison of two different mesalamine formulations for the induction of remission in patients with ulcerative colitis: a double-blind, randomized study. Inflamm Bowel Dis. 2010;16:1567-1574.

47. Prantera C, Kohn A, Campieri M, et al. Clinical trial: ulcerative colitis maintenance treatment with 5-ASA: a 1-year, randomized multicentre study comparing MMX with Asacol. Aliment Pharmacol Ther. 2009;30:908-918.

48. Feagan BG, Macdonald JK. Oral 5-aminosalicylic acid for maintenance of remission in ulcerative colitis. Cochrane Database Syst Rev. 2012;10:CD000544.

49. Feagan BG, Macdonald JK. Oral 5-aminosalicylic acid for induction of remission in ulcerative colitis. Cochrane Database Syst Rev. 2012;10:CD000543.

50. Kane S, Huo D, Magnanti K. A pilot feasibility study on once daily versus conventional dosing mesalamine for maintenance of ulcerative colitis. Clin Gastroenterol Hepatol. 2003;1:170-173.

51. Robinson A. Review article: improving adherence to medication in patients with inflammatory bowel disease. Aliment Pharmacol Ther. 2008;27(Suppl 1):9-14.

52. Hawthorne AB, Rubin G, Ghosh S. Review article: medication nonadherence in ulcerative colitis - strategies to improve adherence with mesalazine and other maintenance therapies. Aliment Pharmacol Ther. 2008;27:1157-1166. 
53. Kane SV, Cohen RD, Aikens JE, et al. Prevalence of non-adherence with maintenance mesalamine in quiescent ulcerative colitis. Am J Gastroenterol. 2001;96:2929-2933.

54. Shale MJ, Riley SA. Studies of compliance with delayed-release mesalazine therapy in patients with inflammatory bowel disease. Aliment Pharmacol Ther. 2003;18:191-198.

55. Lakatos PL. Prevalence, predictors, and clinical consequences of medical adherence in IBD: how to improve it? World J Gastroenterol. 2009; 15:4234-4239.

56. Kane SV, Robinson A. Review article: understanding adherence to medication in ulcerative colitis - innovative thinking und evolving concepts. Aliment Pharmacol Ther. 2010;32:1051-1058.

57. Kane S, Huo D, Aikens J, et al. Medication non-adherence and outcomes of patients with quiescent ulcerative colitis. Am J Med. 2003; 114:39-43.

58. van Hees PAM, van Tongeren JHM. Compliance to therapy in patients on a maintenance dose of sulfasalazine. J Clin Gastroenterol. 1982;4:333-336.

59. Claxton AJ, Cramer J, Pierce C. A systematic review of the associations between dose regimens and medication compliance. Clin Ther. 2001;23:1296-1310.

60. Hussain FN, Ajjan RA, Kapur K, Moustafa M, Riley SA. Once versus divided daily dosing with delayed-release mesalazine: a study of tissue drug concentrations and standard pharmacokinetic parameters. Aliment Pharmacol Ther. 2001;15:53-62.

61. Gandia P, Idier I, Houin G. Is once-daily mesalazine equivalent to the currently used twice-daily regimen? A study performed in 30 healthy volunteers. J Clin Pharmacol. 2007;47:334-342.

62. Das KM, Eastwood MA, McManus JP, et al. Adverse reactions during salicylazosulfapyridine therapy and the relation with drug metabolism and acetylator phenotype. N Engl Med J. 1973;289:491-495.

63. Ford AC, Khan KJ, Sandborn WJ, et al. Once daily dosing vs conventional dosing schedule of mesalamine and relapse of quiescent ulcerative colitis: systematic review and meta-analysis. Am J Gastroenterol. 2011;106:2070-2077.

64. Hayllar J, Bjarnason I. Sulphasalazine in ulcerative colitis: in memoriam? Gut. 1991;32:462-463.

65. Kruis W, Jonaitis L, Pokrotnieks J, et al. Randomised clinical t r i a 1 : a comparative dose-finding study of three arms of dual release mesalazine for maintaining remission in ulcerative colitis. Aliment Pharmacol Ther. 2011;33:313-322.

66. Hanauer SB, Sandborn WJ, Kornbluth A, et al. Delayed-release oral mesalamine at $4.8 \mathrm{~g} /$ day $(800 \mathrm{mg}$ tablet $)$ for the treatment of moderately active ulcerative colitis: the ASCEND II trial. Am J Gastroenterol. 2005;100:2478-2485.

67. Lichtenstein GR, Ramsey D, Rubin DT. Randomised clinical trial: delayed-release oral mesalazine $4.8 \mathrm{~g}$ /day vs $2.4 \mathrm{~g} /$ day in endoscopic mucosal healing - ASCEND I and II combined analysis. Aliment Pharmacol Ther. 2011;33:672-678.

68. Sandborn WJ, Regula J, Feagan BG, et al. Delayed-release oral mesalamine $4.8 \mathrm{~g} /$ day (800-mg tablet) is effective for patients with moderately active ulcerative colitis. Gastroenterology. 2009;137:1934-1943.

69. Kamm MA, Sandborn WJ, Gassull M, et al. Once-daily, highconcentration MMX mesalamine in active ulcerative colitis. Gastroenterology. 2007;132:66-75.

70. Shire plc. Annual Reports from 2008 to 2012. Available from: http:// www.shire.com/shireplc/en/investors/reports. Accessed August 4, 2013.

71. Stallmach A, Häuser W, L'hoest H, et al. Die chronisch entzündlichen Darmerkrankungen Morbus Crohn und Colitis ulcerosa: Herausforderungen an die Versorgung. [The inflammatory bowel diseases Crohns disease and ulcerative colitis: Challenges for health care]. In: Repschläger U, Schulte C, Osterkamp N, editors. Barmer GEK Gesundheitswesen aktuell 2012. [Barmer GEK public health care up to date 2012]. Düsseldorf, Germany: 37 Grad GmbH; 286-309. German.
72. Glaeske G, Schicktanz C. Schriftenreihe zur Gesundheitsanalyse, Band 14. [Monograph series for analysis of health. Volume 14]. Barmer GEK Arzneimittelreport 2012. Available from: https://presse.barmer-gek. de/barmer/web/Portale/Presseportal/Subportal/Infothek/Studien-undReports/Arzneimittelreport/Einstieg-Arzneimittelreport.html. Accessed July 30, 2013. German.

73. Blumenstein I, Tacke W, Filmann N, et al. [Integrated management of patients with chronic inflammatory bowel disease in the RhineMain region: results of the first integrated health-care project IBD in Germany]. Z Gastroenterol. 2013;51:613-618. German.

74. Istock Analyst [homepage on the Internet]. Warner Chilcott Plc: numerous sources of potential upside. February 20, 2013. Available from: http:/www.istockanalyst.com/finance/story/6300463/ warner-chilcott-plc-numerous-sources-of-potentialupside. Accessed August 11, 2013.

75. Warner Chilcott plc. Form 10-K for December 31, 2012. Available from: https://tickerpot.com/symbol/wcrx/1323854/topic/asacol. Accessed August 11, 2013.

76. Kane S, Holderman W, Jacques P, Miodek T. Once daily versus conventional dosing of $\mathrm{pH}$-dependent mesalamine long-term to maintain quiescent ulcerative colitis: Preliminary results from a randomized trial. Patient Prefer Adherence. 2008;2:253-258.

77. Kamm MA, Lichtenstein GR, Sandborn WJ, et al. Randomised trial of once- or twice-daily MMX mesalazine for maintenance of remission in ulcerative colitis. Gut. 2008;57:893-902.

78. Dignass AU, Bokemeyer B, Adamek H, et al. Mesalamine once daily is more effective than twice daily in patients with quiescent ulcerative colitis. Clin Gastroenterol Hepatol. 2009;7:762-769.

79. Sandborn WJ, Korzenik J, Lashner B, et al. Once-daily dosing of delayed-release oral mesalamine (400-mg tablet) is as effective as twice-daily dosing for maintenance of remission of ulcerative colitis. Gastroenterology. 2010;138:1286-1296.

80. Hawthorne AB, Stenson R, Gillespie D, et al. One-year investigatorblind randomized multicenter trial comparing Asacol $2.4 \mathrm{~g}$ once daily with $800 \mathrm{mg}$ three times daily for maintenance of remission in ulcerative colitis. Inflamm Bowel Dis. 2012;18:1885-1893.

81. Lichtenstein GR, Kamm MA, Boddu P, et al. Effect of once- or twicedaily MMX mesalamine (SPD476) for the induction of remission of mild to moderate active ulcerative colitis. Clin Gastroenterol Hepatol. 2007;5:95-102.

82. Kruis W, Kiudelis G, Racz I, et al. Once daily versus three times daily mesalazine granules in active ulcerative colitis: a double-blind, doubledummy, randomised, non-inferiority trial. Gut. 2009;58:233-240.

83. Flourie B, Hagege H, Tucat G, et al. Randomised clinical trial: once- vs twice-daily prolonged-release mesalazine for active ulcerative colitis. Aliment Pharmacol Ther. 2013;37:767-775.

84. Feagan BG, MacDonald JK. Once daily oral mesalamine compared to conventional dosing for induction and maintenance of remission in ulcerative colitis: a systematic review and meta-analysis. Inflamm Bowel Dis. 2012;18:1785-1794.

85. Leifeld L, Pfützer R, Morgenstern J, et al. Mesalazine granules are superior to Eudragit-L-coated mesalazine tablets for induction of remission in distal ulcerative colitis - a pooled analysis. Aliment Pharmacol Ther. 2011;34:1115-1122.

86. Brooks AJ, Lobo AJ. Are mesalazine granules superior to Eudragit-Lcoated mesalazine tablets for induction of remission in distal ulcerative colitis? Aliment Pharmacol Ther. 2012;35:193-194.

87. Sandborn WJ, Kamm MA, Lichtenstein GR, et al. MMX Multi Matrix System mesalazine for the induction of remission in patients with mild-to-moderate ulcerative colitis: a combined analysis of two randomized, double-blind, placebo-controlled trials. Aliment Pharmacol Ther. 2007;26:205-215.

88. Kane SV, Sumner M, Solomon D, Jenkins M. Twelve-month persistency with oral 5-aminosalicylic acid therapy for ulcerative colitis: results from a large pharmacy prescriptions database. Dig Dis Sci. 2011;56:3463-3470. 
89. Yen L, Wu J, Hodgkins PL, Cohen RD, Nichol MB. Medication use patterns and predictors of nonpersistence and nonadherence with oral 5-aminosalicylic acid therapy in patients with ulcerative colitis. J Manag Care Pharm. 2012;18:701-712.

90. Lachaine J, Yen L, Beauchemin C, Hodgkins P. Medication adherence and persistence in the treatment of Canadian ulcerative colitis patients: analyses with the RAMQ database. BMC Gastroenterol. 2013;13:23.

91. Jackson CA, Clatworthy J, Robinson A, Horne R. Factors associated with non-adherence to oral medication for inflammatory bowel disease: a systematic review. Am J Gastroenterol. 2010;105:525-539.

92. Ransford RAJ, Langman MJS. Sulphasalazine and mesalazine: serious adverse reactions re-evaluated on the basis of suspected adverse reaction reports to the Committee on Safety of Medicines. Gut. 2002;51:536-539.

93. D'Haens G, van Bodegraven AA. Mesalazine is safe for the treatment of IBD. Gut. 2004;53:155.

94. Loftus EV Jr, Kane SV, Bjorkman D. Systematic review: short-term adverse effects of 5-aminosalicylic acid agents in the treatment of ulcerative colitis. Aliment Pharmacol Ther. 2004;19:179-189.
95. Feagan BG, Chande N, MacDonald JK. Are there any differences in the efficacy and safety of different formulations of oral 5-ASA used for induction and maintenance of remission in ulcerative colitis? Evidence from cochrane reviews. Inflamm Bowel Dis. 2013;19:2031-2040.

96. Schroeder KW. Review: is mesalamine safe? Gastroenterol Hepatol. 2007;3:878-879.

97. van Staa TP, Travis S, Leufkens HG, Logan RF. 5-aminosalicylic acids and the risk of renal disease: a large British epidemiologic study. Gastroenterology. 2004;126:1733-1739.

98. Gisbert JP, González-Lama Y, Maté J. 5-Aminosalicylates and renal function in inflammatory bowel disease: a systematic review. Inflamm Bowel Dis. 2007;13:629-638.

99. So K, Bewshea BW, Heap GA, et al. 5-Aminosalicylate (5-ASA) induced nephrotoxicity in inflammatory bowel disease. Gastroenterology. 2013;144(Suppl 1):112(A638).

\section{Publish your work in this journal}

Clinical and Experimental Gastroenterology is an international, peerreviewed, open access journal, publishing all aspects of gastroenterology in the clinic and laboratory, including: Pathology, pathophysiology of gastrointestinal disease; Investigation and treatment of gastointestinal disease; Pharmacology of drugs used in the alimentary tract;
Immunology/genetics/genomics related to gastrointestinal disease. This journal is indexed on CAS. The manuscript management system is completely online and includes a very quick and fair peer-review system. Visit http://www.dovepress.com/testimonials.php to read real quotes from published authors.

Submit your manuscript here: http://www.dovepress.com/clinical-and-experimental-gastroenterology-journal 